\title{
Evaluation of Dar Zarrouk Parameters of Parts of Federal University of Petroleum Resources, Effurun, Nigeria
}

\author{
1*BELLO, R; ${ }^{2}$ BALOGUN, AO; ${ }^{2}$ NWOSU, UM \\ ${ }^{I}$ Department of Physics, Federal University of Kashere, Gombe State, Nigeria \\ ${ }^{2}$ Department of Physics, University of Port Harcourt, Port Harcourt, Nigeria \\ *Corresponding Author Email: bellorasaq@fukashere.edu.ng; Tel: +234(0)8036684498
}

\begin{abstract}
This work evaluated the Dar Zarrouk parameters of parts of Federal University of Petroleum Resources, Effurun, Nigeria. The aim of the study is to use Dar Zarrouk parameters to determine the groundwater quality and potentials of the study area. Four (4) Vertical Electrical Sounding (VES) were conducted with maximum electrode spacing of $200 \mathrm{~m}$. The data was acquired using ABEM SAS 4000 Terrameter and processed using IPI2win and Interpex softwares. The Dar Zarrouk parameters evaluated in this work include Longitudinal Conductance (S), Transverse Resistance (T), Coefficient of Electrical Anisotropy $(\lambda)$, Resistivity for the Formation $\left(\rho_{m}\right)$, Reflection Coefficient $\left(\mathrm{R}_{\mathrm{C}}\right)$ and Resistivity Contrast $\left(\mathrm{F}_{\mathrm{C}}\right)$. Results obtained in this work showered that the study area revealed five (5) geologic layers. Resistivity of the aquifer layer ranged from $364.55 \rho_{m}$ (layer 4, VES 3) to $567.66 \rho_{m}$ (layer 4, VES 4). Depths to aquifer level for the study area are $15.06 \mathrm{~m}$ (VES 1), $14.31 \mathrm{~m}$ (VES 2), $12.15 \mathrm{~m}$ (VES 3) and $13.79 \mathrm{~m}$ (VES 4). All the four VESs showed a poorly protected aquifer of the study area. The Dar Zarrouk parameters evaluated showed that the study area has good groundwater potentials with values of Reflection Coefficient ranging from 0.87 to 0.97 , Resistivity Contrast values ranged from 13.78 t0 71.59 while that of Coefficient of Anisotropy ranged from 1.39 to 2.01.
\end{abstract}

\section{DOI: https://dx.doi.org/10.4314/jasem.v23i9.16}

Copyright: Copyright (C) 2019 Bello et al. This is an open access article distributed under the Creative Commons Attribution License (CCL), which permits unrestricted use, distribution, and reproduction in any medium, provided the original work is properly cited.

Dates: Received: 19 July 2019; Revised: 16 September 2019; 22 September 2019

Keywords: Aquifer, Aquifer Protective Capacity, Dar Zarrouk Parameters, Resistivity

Groundwater exploration is gaining more and more importance in Nigeria owning to the ever increasing demand for water supplies, especially in areas with inadequate surface water supplies. Already, ten percent of the world's population is affected by chronic water scarcity and this is likely to rise to onethird by about 2025 (Coker, 2012). High increases in industrial development, urbanization and agricultural production have resulted in freshwater shortages in many parts of the world. As a result of this increasing demand for portable water for these various purposes, there is need to have a planned and optimal utilization of water resources. Aquifer parameter is necessary for the management of groundwater resource. The parameters necessary for the description of the dynamics of aquifer, include, geometry of the pore space, geometry of the rock particles, secondary geologic processes such as faulting and folding and secondary deposition These parameters jointly affect the rate and pattern of groundwater flow (Udoinyang and Igboekwu, 2012). Dar Zarrouk and other geoelectric parameters can be used to recognize and differentiate areas of fresh groundwater aquifers from those of saline groundwater. Water can move through soil as saturated flow, unsaturated flow, or fluid flow (Chandra et al., 2008; Ghassen et al., 2017). Hydraulic conductivity is one of the hydraulic properties of the soil which can be used to determine the behaviour of the soil fluid within the soil system under specified conditions. Hydraulic conductivity determines the ability of the soil fluid to flow through the soil matrix system under a specified hydraulic gradient (Frohlic et al., 1996). Physical characteristics of aquifers such as hydraulic conductivity and transmissivity that control groundwater flow and transport are very important properties and are usually estimated for groundwater flow model calibration. These parameters are also important properties for the assessment of contaminated land, and for safe construction of civil engineering structures (Okiongbo and Oborie, 2015).

Study Area: The study area which is within the College of Science of the Federal University of Petroleum Resources, Effurun, Delta State, Nigeria is in the Niger Delta basin. The basin is made up of three formations, namely the Benin, Agbada and Akata Formations, from the youngest to oldest. The Benin Formation conformably overlies the Agbada Formation. Its lithologic composition is $90 \%$ sand and about $10 \%$ clay and lignite bed. The sands range in size from gravelly, coarse-to fine-grained. It has numerous prolific aquifers. The Agbada Formation 
conformably overlies the Akata Formation in the subsurface. It is a parallic sequence of alternating shale and sands. The Akata Formation, also known as marine shale is composed of shale, silts, clay and turbidity sand at the base of the Delta sequence (Iserhien-Emekeme et al., 2017).

Figures 1 shows the contour map of the study area while figure 2 shows the 3D surface map of the surface area. The two figures reveal that the study area is slightly undulated. The elevation of the study area ranges from $9 \mathrm{~m}$ to $12 \mathrm{~m}$. VES 1 was taking at location which was $10 \mathrm{~m}$ above sea level, VES 2 was taking at location which was $9 \mathrm{~m}$ above sea level, VES 3 was taking at location which was $11 \mathrm{~m}$ above sea level while VES 4 was taking at location which was $12 \mathrm{~m}$ above sea level.

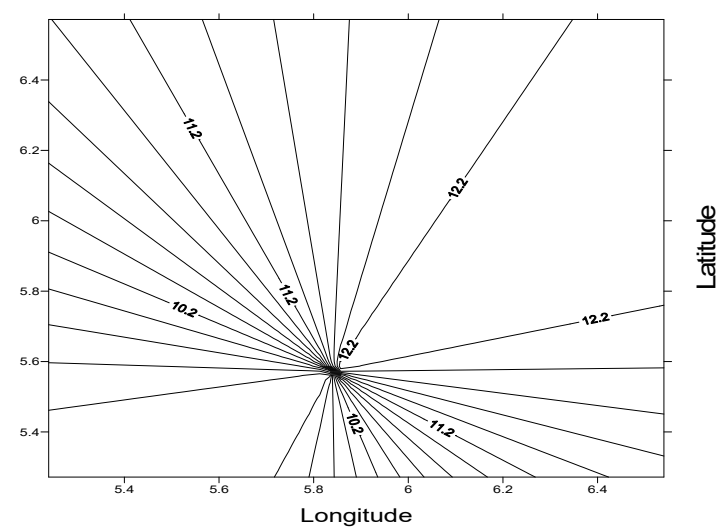

Fig 1: Contour Map of the Study Area

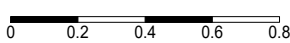

Fig 2: 3D Surface Map of the Study Area

Figures 1 and 2 also showed that the study area was within Latitude N05 $34^{\prime}$ '18.0" and N $05^{\circ} 34^{\prime} 19.0$ "' and longitude E $005^{\circ} 50^{\prime}$ '24.0" and E $005^{\circ} 50^{\prime}$ ' 24.6".

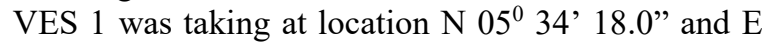
$005^{\circ} 50^{\prime} 24.5^{\prime \prime}, \mathrm{VES} 2$ was at taking at location $\mathrm{N} 05^{\circ}$ 34 ' 18.0" and E $005^{\circ} 50^{\prime}$ '24.0", VES 3 was taking at

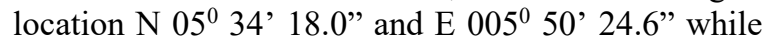
VES 4 was taking at location $\mathrm{N} 05^{0} 34$ ' 19.0" and E $005^{0} 50$ ' 24.6".

\section{MATERIALS AND METHOD}

Four Vertical Electrical Sounding were carried out in the study area using the Schlumberger array with a maximum current electrode spacing $(\mathrm{AB})$ of $200 \mathrm{~m}$ with the ABEM SAS 1000 Terrameter Resistivity Meter. The positions and surface elevations of the VES locations were also recorded with a GPS receiver. For the Schlumberger array used in this work reading of resistance $\mathrm{R}$ of the volume of earth material within the electrical space of the electrode configuration was obtained. The product of geometric factor $\mathrm{K}$ and $\mathrm{R}$ was then made to obtain the apparent resistivity $\left(\rho_{a}\right)$ of the said earth material using equations 1 and 2. Figure 1 shows the Schlumberger Array of Vertical Electrical Sounding used in this work.

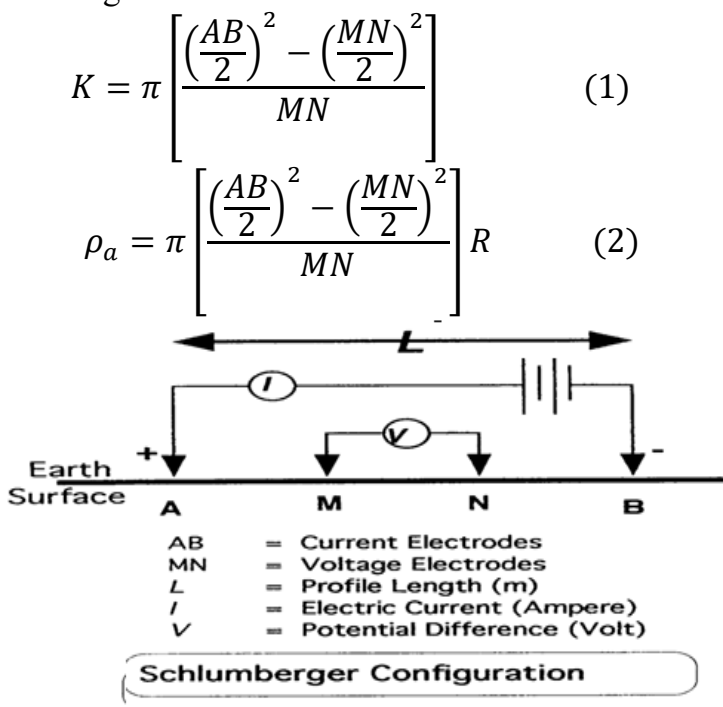

Fig 3: Schlumberger Array of Vertical Electrical Sounding

\section{RESULTS AND DISCUSSION}

The results of this study are presented as sounding curves and geoelectric sections. The electrical resistivity curves obtained showed five layers for the study area. The four VES showed curve types KQH, $\mathrm{KQH}, \mathrm{KQH}$ and KHA type curves respectively (Figures $4-7$ ). The VES curves for the four soundings were shown in figures 4 to 7 , while a protective capacity map of the area was generated from the longitudinal conductance values with the aid of SURFER 8 (2002) Terrain and 3D Surface modeling software as shown in Figures 8 and 9. In all, a total of 4 VES locations, spread over the study area (Figures 1 and 2) were covered. The processed data were subjected to detailed interpretation aimed at unraveling the subsurface groundwater potential through the evaluation of Dar Zarrouk Parameters and aquifer protective capacity of overburden units in the study area. The interpretation assessed the prevalent type curves in the study area, determined the geoelectric properties of the subsurface layers and 
delineated the aquifers in terms of the thickness and cleanliness. The nature of the overburden cap rock was also assessed. The results were presented in form of geoelectric sections and protective capacity maps (Abiola et al., 2009). The apparent resistivity data $\rho$ a $(\Omega \mathrm{m})$ from field measurements were inverted using IPI2WIN resistivity sounding interpretation software and interpex software to determine the true resistivity and depths of subsurface formations. The resulting model curves have fitting errors of $<5 \%$ and exhibit $\mathrm{KQH}, \mathrm{KQH}, \mathrm{KQH}$ and KHA type curves respectively with 5 interpretable geoelectric layers (Figures 4 to 7).

Correlation between the layer lithology and VES is achieved by correlating the resistivity values with the standard values of resistivity as shown in table 1 .

Table 1: Resistivity of common geologic materials.

\begin{tabular}{ll}
\hline Materials & $\begin{array}{l}\text { Normal } \\
\text { Resistivity } \\
\text { (include unit) }\end{array}$ \\
\hline Ash & 4 \\
Laterite & $800-1500$ \\
Lateritic Soil & $120-750$ \\
Gravel (Dry) & 1400 \\
Gravel Saturated) & 100 \\
Dry sandy Soil & $80-1050$ \\
Sand Clay/Clayed Sand & $30-215$ \\
Sand and Gravel & $30-225$ \\
Saturated Landfill & $15-30$ \\
Glacier Ice (Temperate) & $2 \times 10^{6}-1.2 \times 10^{8}$ \\
Glacier Ice (Polar) & $5 \times 10^{4}-3 \times 10^{5}$ \\
Permafrost & $10^{3}->10^{4}$ \\
\hline \multicolumn{2}{c}{ Source: AbdulRahim 2 et $a l .2016$}
\end{tabular}

Source: AbdulRahim et al., 2016.

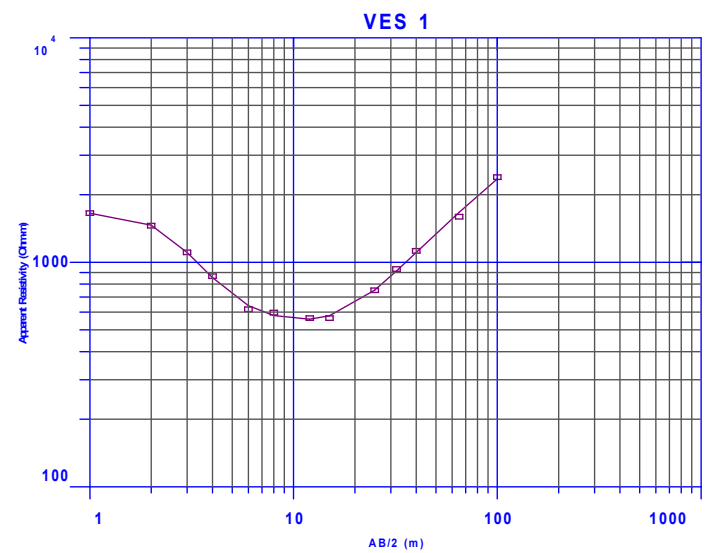

Fig 4: Vertical Electrical Sounding 1

The summary of resistiviy and thicknesssses of the geoelectric/lithology layers within the subsurface are presented in table 2 . The longitudinal conductance and aquifer protective capacity of the study area are presented in table 3, while the aquifer protective capacity as modified by Olusegun et al., (2016) are presented in table 4.

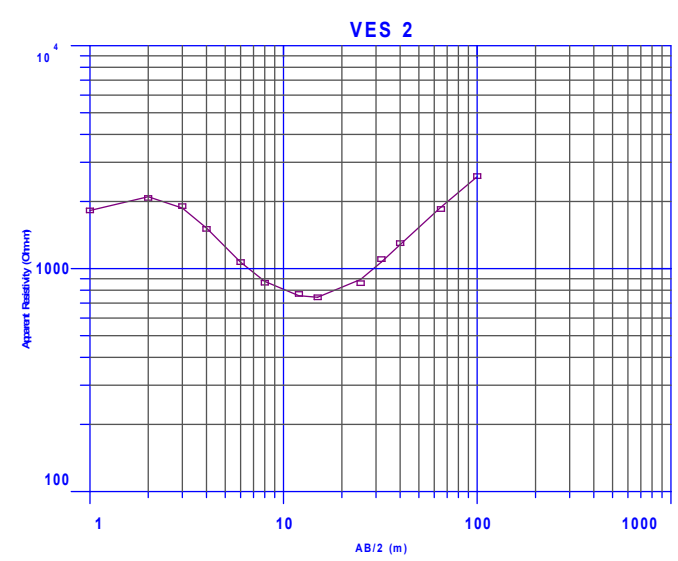

Fig 5: Vertical Electrical Sounding 2

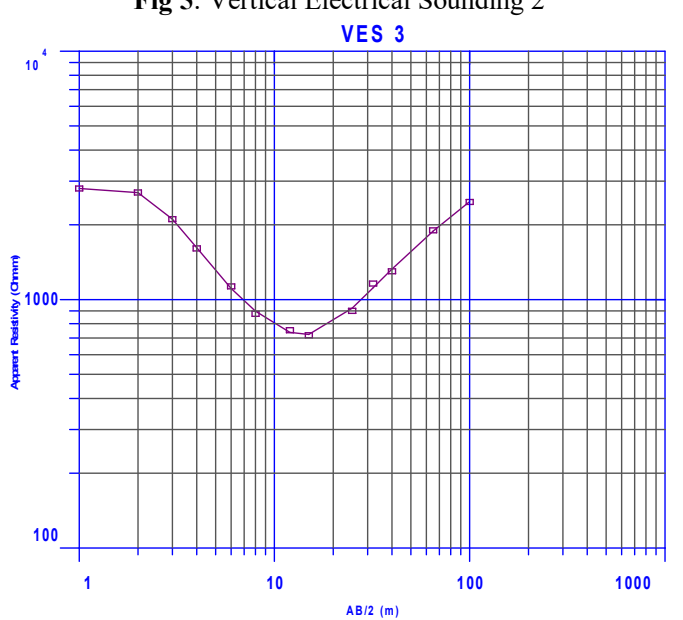

Fig 6: Vertical Electrical Sounding 3

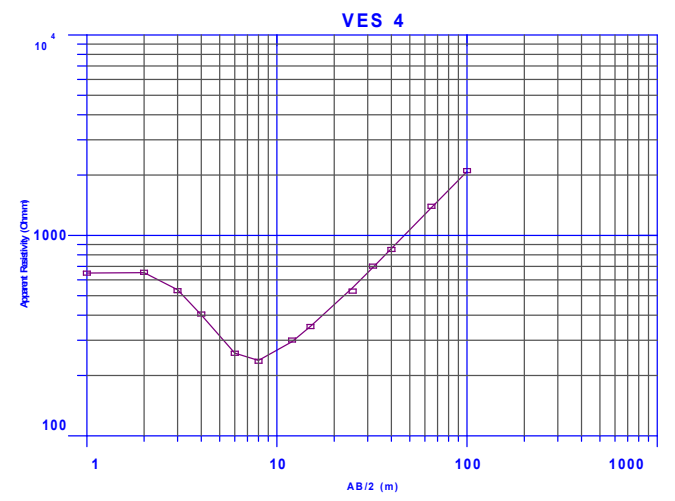

Fig 7: Vertical Electrical Sounding 4

Figure 4 and tables $2-3$ showed that VES 1 is typically KHQ curve. The curve revealed five resistivity layers for VES 1 . The first layer which is the top soil has resistivity of $1654.5 \Omega \mathrm{m}$ with a thickness of $0.48 \mathrm{~m}$. This layer is interpreted to be a weathered layer. The second layer has resistivity of $1962.5 \Omega m$ with a thickness of $0.67 \mathrm{~m}$. This layer is interpreted to be sandy. The third layer has a resistivity value of $544.12 \Omega \mathrm{m}$ with a thickness of $5.12 \mathrm{~m}$. this layer is also interpreted to be sandy clay. Underlaying 
the third layer is the fourth layer with resistivity value of $399.6 \Omega \mathrm{m}$ and a thickness of $8.79 \mathrm{~m}$. This layer is interpreted to be coarse sandy and the layer constitute the aquifer. Underlayin the fourth layer is the fifth layer with resistivity value of $8253.9 \Omega m$ with an undefined thichness. This layer is also interpreted to be sandy. The high resistivity values for layers one and two suggest that the layers might have been conterminated.

Table 2: Summary Table for the Vertical Electrical Sounding Interpretation

\begin{tabular}{|c|c|c|c|c|c|c|c|c|}
\hline \multirow[t]{2}{*}{ VES 1} & \multicolumn{4}{|c|}{ Fitting Error $=1.82$} & \multirow{2}{*}{$\begin{array}{l}\text { VES 2 } \\
\rho_{a}(\Omega m)\end{array}$} & \multicolumn{2}{|c|}{ Fitting Error $=1.82$} & \multirow[b]{2}{*}{ Remarks } \\
\hline & $\rho_{a}(\Omega m)$ & $\mathrm{h}(\mathrm{m})$ & Depth (m) & Remarks & & $\mathrm{h}(\mathrm{m})$ & Depth (m) & \\
\hline Layer 1 & 1654.50 & 0.48 & 0.48 & & 1822.20 & 0.57 & 0.57 & \\
\hline Layer 2 & 1962.50 & 0.67 & 1.15 & & 3690.50 & 0.71 & 1.28 & \\
\hline Layer 3 & 544.12 & 5.12 & 6.27 & & 767.12 & 6.04 & 7.32 & \\
\hline Layer 4 & 399.60 & 8.79 & 15.06 & & 387.96 & 6.99 & 14.31 & \\
\hline Layer 5 & 8253.90 & - & - & & 6965.90 & - & - & \\
\hline Layer 2 & 3551.2 & 0.82 & 1.24 & & 1117.60 & 0.74 & 1.44 & \\
\hline Layer 3 & 980.68 & 4.00 & 5.24 & & 88.75 & 2.34 & 3.78 & \\
\hline Layer 4 & 364.55 & 6.91 & 12.15 & & 567.66 & 10.01 & 13.79 & \\
\hline Layer 5 & 5023.50 & - & - & & 40641.00 & - & - & \\
\hline
\end{tabular}

Table 3: Geoelectric Parameter of the Study Area

\begin{tabular}{|c|c|c|c|c|c|c|}
\hline $\mathrm{S} / \mathrm{N}$ & Layers & $\begin{array}{l}\text { Resistivity } \\
\rho_{a}(\Omega m)\end{array}$ & $\begin{array}{l}\text { Thickness } \\
\text { (m) }\end{array}$ & $S=\sum_{i=1}^{n} \frac{\mathrm{h}_{i}}{\rho_{i}}$ & $\begin{array}{l}\text { Longitudinal Conductivity } \\
\text { of the Protective Layers }\end{array}$ & $\begin{array}{l}\text { Protective } \\
\text { Capacity Rating }\end{array}$ \\
\hline \multirow[t]{5}{*}{ VES 1} & 1 & 1654.50 & 0.48 & $\begin{array}{l}l-1 \\
0.00029\end{array}$ & \multirow[t]{5}{*}{0.024} & \multirow[t]{5}{*}{ Poor } \\
\hline & 2 & 1962.50 & 0.67 & 0.00034 & & \\
\hline & 3 & 544.12 & 5.12 & 0.00094 & & \\
\hline & 4 & 399.60 & 8.79 & 0.02200 & & \\
\hline & 5 & 8253.90 & - & - & & \\
\hline \multirow[t]{5}{*}{ VES 2} & 1 & 1822.20 & 0.57 & 0.00031 & \multirow[t]{5}{*}{0.026} & \multirow[t]{5}{*}{ Poor } \\
\hline & 2 & 3690.50 & 0.71 & 0.00020 & & \\
\hline & 3 & 767.12 & 6.04 & 0.00410 & & \\
\hline & 4 & 387.96 & 6.99 & 0.01900 & & \\
\hline & 5 & 6965.90 & - & - & & \\
\hline \multirow[t]{5}{*}{ VES 3} & 1 & 2801.2 & 0.42 & 0.00014 & \multirow[t]{5}{*}{0.024} & \multirow[t]{5}{*}{ Poor } \\
\hline & 2 & 3551.2 & 0.82 & 0.00023 & & \\
\hline & 3 & 980.68 & 4.00 & 0.00410 & & \\
\hline & 4 & 364.55 & 6.91 & 0.01900 & & \\
\hline & 5 & 5023.50 & - & - & & \\
\hline \multirow[t]{5}{*}{ VES 4} & 1 & 648.76 & 0.70 & 0.0010 & \multirow[t]{5}{*}{0.046} & \multirow[t]{5}{*}{ Poor } \\
\hline & 2 & 1117.60 & 0.74 & 0.00066 & & \\
\hline & 3 & 88.75 & 2.34 & 0.02600 & & \\
\hline & 4 & 567.66 & 10.01 & 0.01800 & & \\
\hline & 5 & 40641.00 & - & - & & \\
\hline
\end{tabular}

Figure 5 and tables $2-3$ showed that VES 2 is typically $\mathrm{KQH}$ curve. The curve revealed five resistivity layers for VES 2 . The first layer which is the top soil has resistivity value of $1822.20 \Omega m$ with a thickness of $0.57 \mathrm{~m}$. This layer is interpreted to be a weathered layer. The second layer has resistivity value of $3690.5 \Omega \mathrm{m}$ with a thickness of $0.71 \mathrm{~m}$. This layer is interpreted to be sandy. The third layer has resistyvity of $767.12 \Omega \mathrm{m}$ with a thickness of $6.04 \mathrm{~m}$. This layer is interpreted as sandy clay. The layer could be a possible aquifer but the high resistivity of the layer may indicate possible contamination of the layer. Underlaying the third layer is the fouth layer with a resistivity value of $387.96 \Omega \mathrm{m}$ with a thickness of 6.99 $\mathrm{m}$. This layer is interpreted to be coarse sandy and the layer constitute the aquifer. Underlaying the fourth layer is the fifth layer with resistivity of $6965.90 \Omega \mathrm{m}$ with an undefined thickness. Figure 6 and tables $2-3$ showed that VES 3 is typically KQH curve. The curve revealed five resistivity layers for VES 3 . The first layer which is the top soil has resistivity value of $2801.20 \Omega \mathrm{m}$ with a thickness of $0.42 \mathrm{~m}$. The second layer has a resistivity value of $3551.20 \Omega \mathrm{m}$ with a thickness of $0.82 \mathrm{~m}$. This layer is interpreted to be sandy. Underlaying the second layer is the third layer with resistivity value of $980.68 \Omega m$ with a thickness of $4.00 \mathrm{~m}$. This layer is interpreted to be sandy clay. Underlaying the third layer is the fourth layer with resistivity value of $364.55 \Omega \mathrm{m}$ with a thickness of 6.91 $\mathrm{m}$. This layer is interpreted to be coarse sandy and constitute the aquifer for the location. Underlaying the fourth layer is the fifth layer with resistivity value of $5023.50 \Omega m$ with an undefined thickness.

Figure 7 and tables $2-3$ showed that VES 4 is typically KHA curve. The curve revealed five 
resistivity layers for VES 4. The first layer which is the top soil has resistivity value of $648.76 \Omega \mathrm{m}$ with a thickness of $0.70 \mathrm{~m}$. Underlaying the first layer is the second layer with resistivity value of $1117.60 \Omega \mathrm{m}$ with a thickness of $0.74 \mathrm{~m}$. This layer is interpreted to be sandy. The third layer has resistivity value of 88.746 $\Omega m$ with a thickness of $2.34 \mathrm{~m}$. This layer is interpreted to be sandy clay. Underlaying the third layer is the fourth layer with the resistivity value of $567.66 \Omega m$ with a thickness of $10.01 \mathrm{~m}$. This layer is interpreted to be coarse sandy and consitute the aquifer for the VES location. The fifth layer has a resistivity value of $40641.00 \Omega \mathrm{m}$ with an undefined thickness.

Table 4: Table showing Aquifer protective Capacity Rating

\begin{tabular}{ll}
\multicolumn{2}{c}{ (Olusegun et al., 2016) } \\
\hline Rating & Remarks \\
\hline Greater than 10 & Excellent \\
5 t0 10 & Very Good \\
0.2 to 4.9 & Moderate \\
0.1 to 0.19 & Weak \\
Less than 0.1 & Poor \\
\hline
\end{tabular}

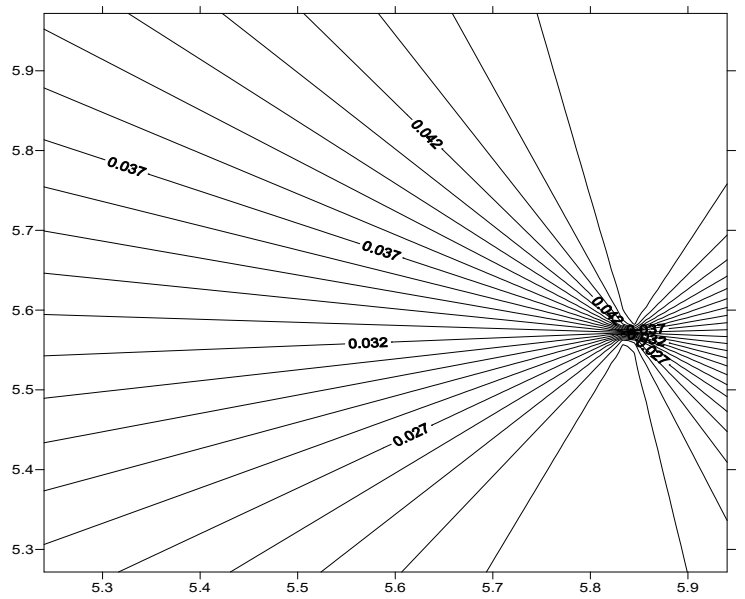

Fig 8: Aquifer Protective Capacity Map of the Study Area

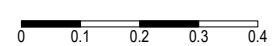

Fig 9: 3D Surface Map of the Aquifer Protective Capacity
Aquifer Protective Capacity: The aquifer protective capacity was determined using the parameters of longitudinal conductance presented in table 3 and the aquifer protective Capacity Rating presented in table 4. The results showed that all the aquifers in VES 1, VES 2, VES 3 and VES 4 showed poor aquifer protective capacity having longitudinal conductance values ranging from 0.024 to 0.046 . The aquifer protective capacity of the study area is also presented in figures $8-9$. Figure 8 showed the aquifer protective capacity map of the study area while figure 9 showed the 3D surface map of the aquifer protective capacity. The aquifer in the study area may be prone to contamination resulting from short residence time in the sandy layers. Usually, groundwater is protected by sufficient protective layers. Groundwater is given adequate protection if silt and clay are found as thick layers above the aquifer.

Dar Zarrouk Parameters: Some parameters are generally very important in the understanding and interpretations of geological model (Egbai and Iserhien-Emekeme, 2015). These parameters are related to different combination of the thickness and resistivity of each geoelectric layers in the model (Braga et al, 2006). For a sequence of horizontal, homogeneous and isotropic layers of resistivity $\rho_{i}$ and thickness $h_{i}$, the Dar Zarrouk parameters (longitudinal conductance $\mathrm{S}$ and transverse resistance $\mathrm{T}$ are respectively defined as :

$$
\begin{gathered}
S=\sum_{i=1} \frac{h_{i}}{\rho_{i}} \\
T=\sum_{i=1} h_{i} \rho_{i}
\end{gathered}
$$

And

If the total thickness of the layers in the geoelectric section considered is $\mathrm{H}$, then the average longitudinal resistivity $\rho_{L}$ is given by

$$
\rho_{L}=\sum_{i=1} \frac{h_{i}}{s_{i}}
$$

And the average transverse resistance $\rho_{l}$ is given by

$$
\rho_{l} \cdot=\sum \mathrm{T}_{\mathrm{i}} / \mathrm{h}_{\mathrm{i}}
$$

$\rho_{l}$ is always greater than $\rho_{L}$. Therefore, the entire section will thus be anisotropic with regard to electrical resistivity. The coefficient of electrical anisotropy is defined as

$$
\lambda=\sqrt{\frac{\rho_{l}}{\rho_{L}}}
$$

Where $\lambda$ is real and greater than 1 . 
A mean value of resistivity for the formation $\left(\rho_{m}\right)$ can be defined as

$$
\rho_{m}=\sqrt{\rho_{L} \rho_{l}}
$$

The reflection coefficient $\left(\mathrm{R}_{\mathrm{C}}\right)$ and resistivity contrast $\left(\mathrm{F}_{\mathrm{C}}\right)$ of the fresh basement rock of the study area was calculated using the method of Oladunjoye and Jekayinfa (2015).

And

$$
R_{C}=\frac{\rho_{n}-\rho_{n-1}}{\rho_{n}+\rho_{n-1}}
$$

$$
F_{C}=\frac{\rho_{n}}{\rho_{n-1}}
$$

Where $\rho_{n}$ is the layer resistivity of the $\mathrm{n}^{\text {th }}$ layer and $\rho_{n-1}$ is the layer resistivity overlying the nth layer.

The Dar Zarouk parameters of the study area were evaluated based on the weathered layer thickness, resistivity of overburden thickness, transverse resistance $(T)$, coefficient of electrical anisotropy $(\lambda)$, reflection coefficient $\left(R_{C}\right)$, formation resistivity $\left(\rho_{m}\right)$ and resistivity contrast $\left(\mathrm{F}_{\mathrm{C}}\right)$. Values of various

\begin{tabular}{|c|c|c|c|c|c|c|}
\hline VES & $\begin{array}{c}\text { Reflection } \\
\text { Coefficient } \\
\left(\mathrm{R}_{\mathrm{c}}\right)= \\
\frac{\rho_{n}-\rho_{n-1}}{\rho_{n}+\rho_{n-1}}\end{array}$ & $\begin{array}{l}\text { Resistivity } \\
\text { Contrast } \\
\left(\mathrm{F}_{\mathrm{c}}\right)=\frac{\rho_{n}}{\rho_{n-1}}\end{array}$ & $\begin{array}{l}\text { Longitudinal } \\
\text { Resistivity } \\
\left(\rho_{L}\right)=\frac{\mathrm{h}}{s} \\
(\Omega m)\end{array}$ & $\begin{array}{c}\text { Transverse } \\
\text { Resistivity } \\
\left(\rho_{l}\right)=\frac{T}{\mathrm{~h}} \\
(\Omega m)\end{array}$ & $\begin{array}{l}\text { Coefficient of } \\
\text { Anisotropy } \\
(\lambda)=\sqrt{\frac{\rho_{l}}{\rho_{L}}}\end{array}$ & $\begin{array}{l}\text { Resistivity of } \\
\text { Formation } \\
\left(\rho_{m}\right)= \\
\sqrt{\rho_{l} \rho_{L}}(\Omega m)\end{array}$ \\
\hline 1 & 0.91 & 20.66 & 300.68 & 828.73 & 1.39 & 124589.70 \\
\hline 2 & 0.89 & 17.96 & 303.91 & 1183.06 & 1.95 & 179768.20 \\
\hline 3 & 0.87 & 13.78 & 310.18 & 1246.76 & 2.01 & 193357.30 \\
\hline 4 & 0.97 & 71.59 & 199.13 & 741.62 & 1.86 & 73839.20 \\
\hline
\end{tabular}
formation parameters are presented in table 5 .

Table 5: Evaluation of Dar Zarrouk Parameters

The reflection coefficient $\left(\mathrm{R}_{\mathrm{C}}\right)$ is a measure of the degree of fracture in an area. It could also indicate the density of formation in the aquifer. Areas of low reflection coefficient value have high water potentials. The results of the area studied in this work showed that the reflection coefficient values ranged from 0.87 to 0.97 indicating high groundwater potentials.

Low values of resistivity contrast indicate high groundwater potentials. The values of resistivity contrast in this work ranged from 13.78 to 71.59 . This shows that the four VES locations studied in this work have high groundwater potentials except VES 4.

Low values of coefficient of anisotropy $(\lambda)$ may be indicating high - density water - filled aquifer usually determined for a basement complex. Its determination in this work was to see if it can also provide an insight into groundwater potential in the study area. In this work, the values of coefficient of anisotropy obtained ranged from 1.39 (VES 1) to 2.01 (VES 3). These values are considered high $\lambda$ values.

The influence of pore structure on the resistance of sample gives an indication of the resistivity of the formation. The resistivity of formation containing hydrocarbon is usually very high (Okhue and Olorunfemi, 1991). The values of resistivity of formation obtained in this work ranged between $73839.20(\Omega m)($ VES 3) and $193357.30(\Omega m)$ (VES $4)$. These values are considered high and might indicate that the study area is contaminated with hydrocarbon.
Conclusion: This work evaluated Dar Zarrouk parameters of parts of Federal University of Petroleum Resources, Effurun, Nigeria to determine groundwater quality and potentials. Results obtained in this work showered that the study area revealed five (5) geologic layers. Results also showed that the study area has poor aquifer protective capacity. The Dar Zarrouk parameters evaluated showed that the study area has good groundwater potentials.

\section{REFERENCES}

AbdulRahim, A; Syed SA; Nazish N; Waqas A; Sarfraz K; Muhammad YK; Muhammad W (2016). Correlation of electrical resistivity of soil with geotechnical engineering parameters at Wattar area district Nowshera, Khyber Pakhtunkhwa, Pakistan. J. Himalay. Eart. Sci. 49(1): 124-130

Braga, AC; De Oliveira, FWM; Dourado, JC (2006). Resistivity (DC) method Applied to aquifer Protection Studies. Revist. Brasilei. De. Geofisi. 24(4): 573-581.

Abiola, O; Enikanselu, PA; Oladapo, MI (2009). Groundwater potential and aquifer protective capacity of overburden units in Ado-Ekiti, southwestern Nigeria. Inter. J. Physi. Sci. 4 (3): 120-132.

Chandra, S; Ahmed, S; Ram, A; Dewandel, B (2008). Estimation of Hard Rock Aquifers Hydraulic 
Conductivity from the Geoelectrical Measurements: A Theoretical Development with Field Application. J. Hydrol. 357: 218-227.

Coker, OJ (2012). Vertical electrical sounding (VES) methods to delineate potential groundwater aquifers in Akobo area, Ibadan, South-western, Nigeria. J. Geol. Mini. Res. 4(2): 35-42.

Egbai, JC; Iserhien-Emekeme, RE (2015). Aquifer Transmissivity Dar Zarrouk Parameters and Groundwater Flow Direction in Abudu, Edo State, Nigeria. Inter. J. Sci. Environ. Technol. 4(3): 628-640.

Frohlic, RK; Fisher, JJ; Summerly, E (1996). Electrical Hydraulic Conductivity Correlation in Fractured Crystalline Beddrock, Central Land fill, Rhod Island, USA. J. Appl. Geophy. 35: 249-259.

Ghassen, L; Sunday, EE; Okechukwu, EA (2017). Delineation of Aquifers Using Dar Zarrouk Parameters in Parts of Akwa Ibom, Niger Delta, Nigeria. J. Hydroge. Hydrolo. Engr. 6(1): 1-8

Iserhien-Emekeme, R; Ofomola, MO; Bawallah, M; Anomohanran, O (2017). Lithological Identification and Underground Water Conditions in Jeddo Using Geophysical and Geochemical Methods. Hydrol. J. 4(42): 1 - 15.
Okiongbo, KS; Oborie, E (2015). Investigation of Relationships between Geoelectric and Hydraulic Parameters in a Quaternary Alluvial Aquifer in Yenagoa, Southern Nigeria. Ife. J. Sci. 17(1): 163-172.

Okhue, ET; Olorunfemi, MO (1991). Electrical resistivity investigation of a typical basement complex area- The Obafemi Awolowo University campus case study. J. Min. Geolo. 27(2):66-70.

Oladunjoye, M; Jekayinfa, S (2015). Efficacy of Hummel (Modified Schlumberger) Arrays of Vertical Electrical Sounding in Groundwater Exploration: Case Study of Parts of Ibadan Metropolis, Southwestern Nigeria. Hindawi Publishing Corporation. Int. J. Geoph. 2015: 124.

Olusegun, OA Adeolu, OO; Dolapo, FA (2016). Geophysical Investigation for Groundwater Potential and Aquifer Protective Capacity around Osun State University (UNIOSUN) College of Health Sciences. Amer. J. Water. Res. 4(6); 137143.

Udoinyang, IE; Igboekwe, MU (2012). Aquifer Transmissivity, Dar Zarrouk Parameters and the Direction of Flow of suspended particulate Mattee in Boreholes in MOUAU and the Kwa Ibo River Umudike-Nigeria. Gree. J. Phy. Sci. 2(3): 70-84 